\title{
REINTERPRETACJA HISTORII W KSIĘGACH KRONIK. PRZYPADEK KRÓLA MANASSESA
}

Relacja między dziejami Królestwa Judy opisanymi w Księgach Kronik a historią tego królestwa opowiedzianą na kartach Ksiąg Królewskich jest zagadnieniem interesującym i szeroko dyskutowanym. Wiele studiów zostało poświęconych pracy Kronikarza, który, posługując się materiałem Ksiąg Królewskich (tzw. Vorlage), nadawał mu niejednokrotnie nową formę, opuszczał niektóre wątki bądź też włączał nowe. Porównanie obydwu projektów historiograficznych rodzi pytania o strategię narracyjną, założenia redakcyjne czy kwestie teologiczne, którymi kierował się autor biblijny w doborze materiału historycznego i budowaniu struktury swoich opowiadań.

Niezwykle interesującym przypadkiem jest opowiadanie o królu Manassesie, które w Księgach Kronik ma inną konstrukcję i wymowę niż w Księgach Królewskich. ${ }^{1}$ Zestawiając ze sobą obydwa opowiadania, można wyraźnie zauważyć, że tylko pierwsza ich część - z niewielkimi różnicami - jest narracją prowadzoną paralelnie, ukazującą ciągłość materiału historiograficznego między Księgami Kronik a Księgami Królewskimi (2Krn 33, 1-9 = 2Krl 21, 1-9). Z obydwu

1 Szczegółową analizę biblijnego obrazu Manassesa w Księgach Królewskich oraz w Księgach Kronik zob. K.A.D. S m e li k, Converting the Past: Studies in Ancient Israelite and Moabite Historiography, OTS 28, Leiden-New York-Köln 1992, s. 129-189; F. S t a v r a k o p o u 1 o u, King Manasseh and Child Sacrifice: Biblical Distortions of Historical Realities, Beihefte zur Zeitschrift für die alttestamentliche Wissenschaft 338, Berlin 2004, s. 15-59; G.N. K n o p p e r s, Saint or Sinner?: Manasseh in Chronicles, w: J. C o r l e y, H.W.M. v o n G rol (red.), Rewriting Biblical History: Essays on Chronicles and Ben Sira in Honor of Pancratius C. Beentjes, Berlin-New York 2011, s. 211-229. 
opowiadań dowiadujemy się bowiem o bezbożnych i bałwochwalczych poczynaniach Manassesa. Natomiast w dalszej ich części interpretacja losów króla rozwija się w przeciwnych kierunkach. W narracji Ksiąg Królewskich jednoznacznie negatywnie ocenia się jego rządy, obarczając go osobistą odpowiedzialnością za najazd babiloński i upadek Królestwa Judy (2Krl 21, 10-18; zob. też $2 \mathrm{Krl} 23$, 26-27; 24, 3-4). Opowiadanie Kronikarza wydobywa natomiast nowy materiał historiograficzny, przedstawiający Manassesa w pozytywnym świetle jako nawróconego grzesznika, który zrehabilitował się przed Bogiem i swoimi reformami oraz dziełami budowlanymi przywrócił świetność królestwu (2Krn 33, 10-20). W ten oto sposób opowiadanie Kronikarza nie jest jedynie prostym odtworzeniem dziejów Manassesa na podstawie materiału historiograficznego Ksiąg Królewskich, ale staje się pełną reinterpretacją jego losów.

Alternatywne przekazy o Manassesie w Piśmie Świętym rodzą pytania o strategię narracyjną i teologiczne przesłanie płynące z tych dwóch różnych opowiadań. Dlaczego Kronikarz pomija te elementy tradycji o Manassesie, które wskazują na jego osobistą odpowiedzialność za upadek Judy? Dlaczego przedstawia go w innym świetle niż historiograf Ksiąg Królewskich? Jaką wartość historyczną ma materiał własny Kronikarza? To tylko wybrane pytania, na które będziemy szukać odpowiedzi w niniejszym studium. Nasze badania podzieliliśmy na kilka etapów. Po pierwsze, porównamy materiał wspólny tradycji o Manassesie, wskazując na punkty styczne między opowiadaniem z Ksiąg Królewskich a Księgami Kronik. Po drugie, poddamy analizie materiał własny obu opowiadań, podkreślając rozbieżności między obiema tradycjami i ich teologiczne konsekwencje. W kolejnym etapie zastanowimy się nad prawdopodobną strategią narracyjną leżącą u podstaw danej wizji losów Manassesa i jej znaczeniem dla adresatów tych pism. Zajmiemy się też zagadnieniem historycznej rekonstrukcji postaci Manassesa, jej możliwościami i ograniczeniami. 


\section{Materiał wspólny tradycji o Manassesie}

Na początku opowiadania o Manassesie pojawia się materiał historyczny wspólny dla Ksiąg Królewskich i Ksiąg Kronik (2Krl 21, $1-9=2 \mathrm{Krn} 33,1-9) .{ }^{2}$ Obaj historiografowie przedstawiają tu postać króla i podają podstawowe informacje na temat jego rządów. Następnie dokonują jednoznacznie negatywnej oceny jego poczynań i trzykrotnie przywołują jego grzechy o charakterze bałwochwalczym, godzące bezpośrednio w jedyność kultu Boga JHWH. Obaj historiografowie dwukrotnie przywołują proroctwa odnoszące się do Jerozolimy jako miejsca wybranego przez Boga, w którym umieści On swoje imię. Obaj autorzy biblijni wskazują także na fakt, że warunkiem pomyślności Judy i jej mieszkańców jest przestrzeganie Prawa Mojżeszowego. Materiał wspólny obu narracji kończy się podsumowaniem piętnującym bezbożność ludu, który Manasses zwiódł swoimi praktykami.

W tabeli 1. zestawiono materiał wspólny 2Krl 21, 1-9 i 2Krn 33, 1-9 (wyrażenia pośrodku odnoszą się do obu wersji; rozbieżności, dodatki i pominięcia zaznaczono odpowiednio w kolumnach odnoszących się do 2Krl 21 bądź do 2Krn 33).

Zestawienie z tabeli 1. udowadnia, że zasadnicza treść obydwu opowiadań jest wspólna. ${ }^{3}$ Różnice, które obserwujemy, mają głównie znaczenie stylistyczne i retoryczne. Dla przykładu można wskazać tu pewną tendencję w 2Krn 33 do używania liczby mnogiej zamiast pojedynczej w $2 \mathrm{Krl} 21$ (w. 3: Baalom versus Baalowi, aszery versus aszerę; w. 6a: synów versus syna). Ponadto opowiadanie Kronikarza

2 Niektóre wspólne elementy opowiadania o Manassesie znajdują się także w jego zakończeniu ( $2 \mathrm{Krl} 21,17-18 \approx 2 \mathrm{Krn} 33,18-20)$, o ile jednak tekst $2 \mathrm{Krn} 33$, 1-9 przytacza prawie verbatim $2 \mathrm{Krl} 21$, 1-9, o tyle $2 \mathrm{Krn} 33$, 18-20 zawiera wyraźnie przepracowany tekst $2 \mathrm{Krl}$ 21, 17-18. Zakończenie obu opowiadań omówię w rozdziale poświęconym materiałowi własnemu tradycji o Manassesie.

3 W celu uproszczenia zapisu i ze względów dydaktycznych pominąłem w tabeli niektóre różnice leksykalne i stylistyczne między tekstem hebrajskim $2 \mathrm{Krl} 21$, 1-9 a 2Krn 33, 1-9. Różnice te nie mają, w mojej ocenie, większego znaczenia dla ogólnej treści opowiadania. 
KRZYSZTOF KINOWSKI

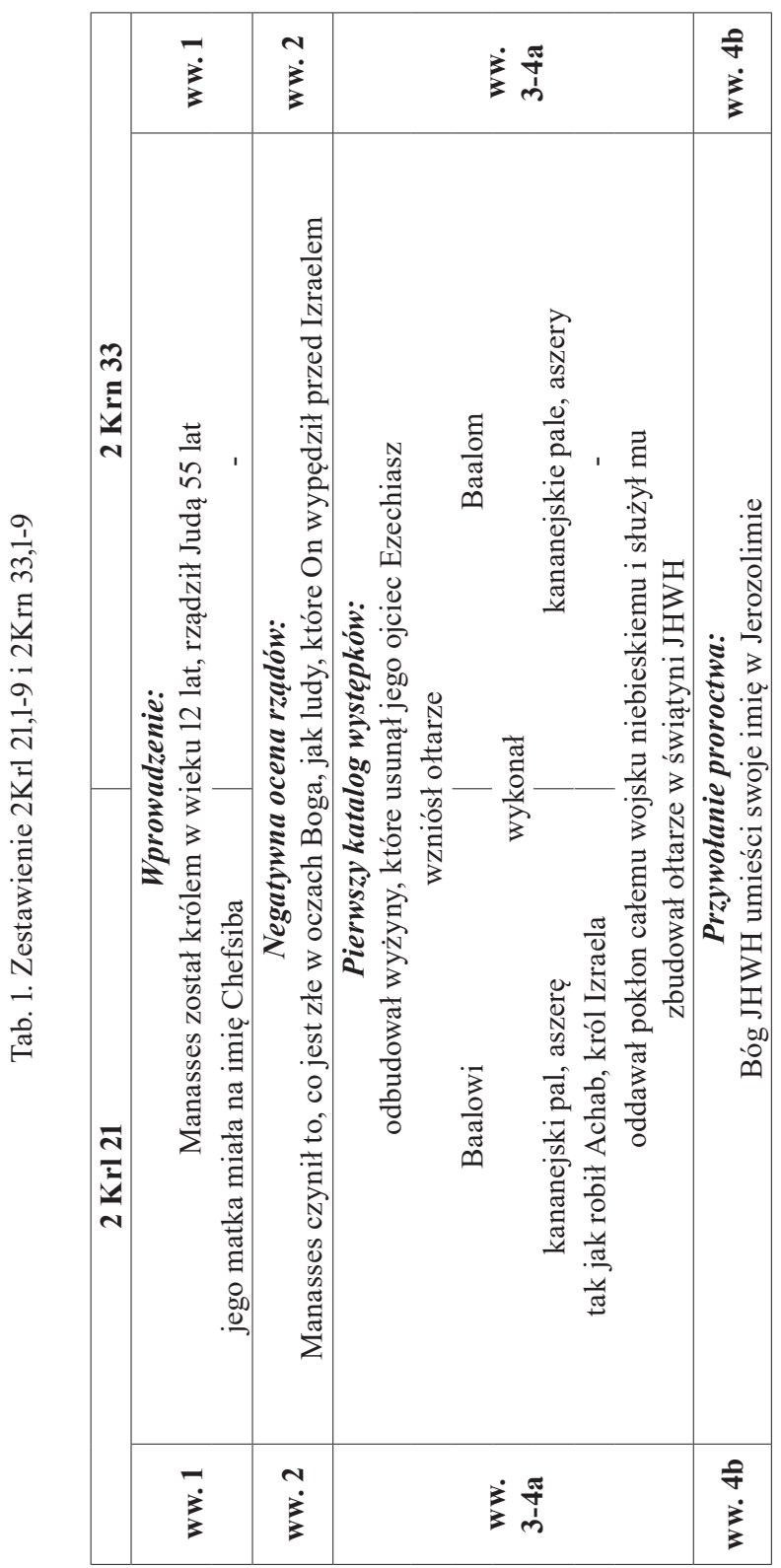


REINTERPRETACJA HISTORII W KSIĘGACH KRONIK




pomija niektóre elementy typowe dla historiografii Ksiąg Królewskich, takie jak podawanie imienia matki króla w przypadku monarchów judzkich (w. 1) czy odniesienie do króla izraelskiego Achaba (w. 3). Kronikarz dopowiada natomiast i rozszerza niektóre szczegóły opowiadania, np. uściśla miejsce ,przeprowadzania przez ogień” (w. 6a, Dolina Synów Hinnoma), podaje termin oznaczający praktykowanie magii (czas. $k \bar{a} \check{s} a \bar{p}$ piel; w. 6a) obok wyrażeń określających uprawianie wróżbiarstwa (czas. 'ānan poel) i przepowiadanie przyszłości (czas. nāḥaš piel), oraz rozszerza wezwanie do przestrzegania Prawa (tôrāh; w. 8) o postanowienia (huqqîm) i nakazy (mišpāț̂িm). Kronikarz doprecyzowuje także, że Manasses zwiódł „Judę i mieszkańców Jerozolimy” (w. 9), podczas gdy Druga Księga Królewska posługuje się tylko zaimkiem „,ich”. W innym miejscu (w. 7a) Księgi Kronik zastępują wyrażenie ,posag Aszery” (pesel $h \bar{a} a \breve{a} s \bar{e} r \bar{a} h)$ z Ksiąg Królewskich bardziej ogólnym określeniem ,posąg rzeźbiony” (dosł. „posąg-rzeźba” - pesel hassemel).

Różnice między tekstem 2Krn 33, 1-9 a 2Krl 21, 1-9 wskazuje na nieznaczne przesunięcie akcentów w opowiadaniu. Tekst Ksiąg Kronik jest bardziej emfatyczny i ekspresyjny, mocniej wskazuje na winę Manassesa przez pomnożenie jego występków (np. używa liczby mnogiej), ich uszczegółowienie (np. przywołuje Dolinę Synów Hinnoma i dodaje termin na praktykowanie magii) czy pominięcie jednego z odniesień do zbiorowej winy ludu. Kronikarz używa także języka bardziej eksplicytnego i perswazyjnego (np. dodaje do Prawa także postanowienia i nakazy; uściśla, kogo zwiódł Manasses). Ponadto wyrażenie „posąg rzeźbiony” wydaje się mieć większą siłą oddziaływania na adresatów Ksiąg Kronik, czyli powygnaniową wspólnotę Izraela, gdyż rozszerza zakres pojęcia idolatrii do jakiegokolwiek wyobrażenia pogańskiego bożka. ${ }^{4}$

4 Por. Ph. A b a d i e, From the Impious Manasseh (2 Kings 21) to the Convert Manasseh (2 Chronicles 33): Theological Rewriting by the Chronicler, w: M.P. G r a h a m, S.L. M c K e n z i e, G.N. K n o p p e r s (red.), The Chronicler as Theologian: Essays in Honor of Ralph W. Klein, JSOT.SS 371, London-New York 2003, s. 97. 
Te obserwacje nie zmieniają faktu, że ogólne przesłanie 2Krn 33, 1-9 pozostaje w zbieżności z 2Krl 21, 1-9. Kronikarz ukazuje króla Manassesa jako bezbożnika i bałwochwalcę, który oddał się praktykom ludów pogańskich, uderzył bezpośrednio w jedyność kultu Boga JHWH i zbezcześcił Jego świątynię w Jerozolimie, umieszczając w niej ołtarze pogańskie i rzeźbiony posąg bożka. Dramatyzm tej sytuacji podkreślono przez dwukrotne przywołanie słów Boga o wybraniu tego miejsca dla Jego imienia i niemożności pogodzenia tego z kultem bałwochwalczym Manassesa. Jak przestroga brzmią więc słowa historiografa, że obietnica Bożej Opatrzności nad ludem jest uwarunkowana przestrzeganiem Prawa Mojżeszowego. Podobną wymowę ma stwierdzenie, że Manasses zwiódł swój lud tak bardzo, że bezbożne czyny Judejczyków przewyższyły nawet praktyki ludów wypędzonych przed nimi. Wszystko to musi skłaniać do postawienia poważnych pytań o przyszłość Jerozolimy, Judy i całego narodu.

\section{Materiał własny tradycji o Manassesie}

Punktem zwrotnym opowiadania o bezbożnym królu jest 2Krn 33, 10. Od tego miejsca narracja Kronikarza prowadzona jest w innym kierunku niż opowiadanie z Ksiąg Królewskich. Podczas gdy 2Krl 21, 10-18 kontynuuje wątek oskarżania króla i ukazuje konsekwencje jego działań dla całego narodu (dalsza kolpewolizacja Manassesa, czyli intensyfikacja jego winy), Kronikarz wprowadza wątek kary Bożej wymierzonej bezpośrednio w króla i informuje o jego nawróceniu oraz powrocie do łask przed Bogiem (rehabilitacja Manassesa). Przyjrzymy się obu procesom, aby następnie wydobyć elementy charakterystyczne dla każdego z tych opowiadań.

Napiętnowanie Manassesa w 2Krl 21, 10-18; 23, 26-27; 24, 3-4

Fabuła opowiadania w 2Krl 21, 10-18 rozwija wątek oskarżania Manassesa. Historiograf przywołuje tu proroctwo, które Bóg przekazał przez swoje sługi proroków (w. 10). Treść wyroczni odnosi się wpierw (w. 11) bezpośrednio do występków Manassesa, które 
osiągnęły bezprecedensową skalę, oraz do faktu, że doprowadził do grzechu także swój kraj (tworzą się tu związki wewnątrztekstowe między proroctwem a tym, co zostało już wyrażone w ww. 2 i 9). Historiograf podaje następnie jednoznaczny wyrok Boży: Jerozolima i Juda ulegną zagładzie (w. 12), a ich mieszkańcy staną się łupem i pastwą najeźdźców (w. 14). Przedstawienie tego wyroku dokonuje się za pomocą dwóch obrazów.

Pierwszy z nich odnosi się do zniszczenia Samarii, stolicy Królestwa Północnego, i wytracenia rodu Achaba (w. 13a), uważanego za najbardziej bezbożnego monarchę Izraela (zob. 1Krl 16, 30; 21, 25). Nie jest to przypadkowe porównanie, bo lista grzechów Manassesa w 2Krl 21, 3-4a jest podobna do występków Achaba w 1Krl 16, 31-33, którego ród został skazany na unicestwienie właśnie za bezbożność i idolatrię (1Krl 21, 21-24). Podobnie dzieje się z upadkiem Samarii (2Krl 17, 5-6), który historiograf interpretuje w terminach teologicznych jako skutek bałwochwalstwa i odstąpienia od prawowiernego kultu Boga JHWH (2Krl 17, 7-23). Wiele występków wyszczególnionych w tej perykopie jako powód karzącego gniewu Boga przypomina oskarżenie wysuwane przeciw Manassesowi w 2Krl 21, 1-9 (zob. szczególnie 2Krl 17, 16-17: wykonanie świętych palów, oddawanie pokłonu wojsku niebieskiemu, przeprowadzanie dzieci przez ogień, uprawianie wróżbiarstwa i czarnoksięstwa). Cel pragmatyczny tego zestawienia jest jasny: Jerozolimę, Judę i ich mieszkańców spotka ten sam los co Samarię i ród Achaba.

W drugim obrazie zniszczenie Jerozolimy jest porównane do wytarcia misy - w domyśle: $\mathrm{z}$ brudu - którą odwraca się następnie do góry dnem (2Krl 21, 13b). Metafora ta sugeruje, że owo zniszczenie będzie jednocześnie oczyszczeniem Jerozolimy i Judy z bałwochwalstwa Manassesa. Motyw odwrócenia misy dnem do góry nie oznacza jednak całkowitej destrukcji czy anihilacji, lecz zniszczenie z perspektywą odnowienia.

Ostatnie słowa analizowanego proroctwa uzasadniają Boży wyrok przeciw Jerozolimie i Judzie jako skutek bezbożności Judejczyków, którzy od wyjścia z Egiptu nie przestali obrażać Boga swoimi czynami (w. 15). To stwierdzenie niewątpliwie przesuwa akcent 
z osobistej winy Manassesa za nadchodzącą katastrofę na wspólną odpowiedzialność mieszkańców Jerozolimy i Judy. Tworzy ono także suspens w fabule, gdyż realizacja Bożego wyroku nastąpi dopiero w toku wydarzeń 2Krl 24-25.

W dalszej części opowiadania o Manassesie historiograf przywołuje jeszcze jeden występek Manassesa: przelał on krew niewinnych ludzi w Jerozolimie w takiej ilości, że wypełnił nią całe miasto po brzegi $(2 \mathrm{Krl} 21,16)$. Ta zbrodnia dodaje do oskarżenia przeciw królowi grzech o innym charakterze niż przy toczone dotychczas. ${ }^{5} \mathrm{~W}$ oczach historiografa Ksiąg Królewskich Manasses był nie tylko bezbożnikiem i bałwochwalcą, ale także mordercą, który zamiast dbać o dobrobyt swojego ludu, krwawo go prześladował. Ten zarzut ma swoje dalsze konsekwencje, gdyż, patrząc w kontekście intertekstualnym, nieprawnie przelana krew domaga się pomszczenia w postaci śmierci sprawcy zbrodni (Rdz 9, 6; Lb 35, 33), ${ }^{6}$ a w przypadku niewykrycia mordercy, przeprowadzenia rytu oczyszczenia popiołem z czerwonej krowy (Pwt 21, 1-9). Niedopełnienie tych czynności prowadzi do nieodwracalnego skalania ziemi krwią, a wtedy nie mógłby na niej mieszkać ani lud, ani sam Bóg (Lb 35, 33-34). ${ }^{7}$ Zatem w oczach historiografa nieodkupiona wina za krwawe zbrodnie Manassesa stanowiła nie mniejsze zagrożenie dla istnienia Królestwa Judy niż jego bezbożność i idolatria.

5 Niezgodne z prawem zabójstwo jest zbrodnią wymierzoną przeciwko porządkowi społecznemu. Przepisy wyrażone w Pwt 19, 10-13 zakazują przelewania niewinnej krwi w kraju, który Bóg daje w dziedzictwo swojemu narodowi. Tekst ten nakazuje bezwarunkowe usunięcie winnego przelewu niewinnej krwi z Izraela; por. P.S.F. v a n K e u l e n, Manasseh through the Eyes of the Deuteronomists: The Manasseh Account (2 Kings 21:1-18) and the Final Chapters of the Deuteronomistic History, OTS 38, Leiden 1996, s. 140.

6 Jedynym wyjątkiem jest nieumyślne zabójstwo. Jego sprawca może schronić się w jednym z tzw. miast ucieczki, a jego wina zostanie odkupiona wraz z naturalną śmiercią ówcześnie urzędującego najwyższego kapłana (Lb 35, 28. 32).

7 Por. Kpł 18, 24-30, gdzie stwierdza się, że mieszkańcy Kanaanu zostali pozbawieni prawa do swojej ziemi z powodu ich obrzydliwych występków, które uczyniły ziemię nieczystą. 
Fabuła opowiadania o Manassesie w 2Krl 21 jest pozbawiona jednak rozwiązania. Po przytoczeniu wszystkich grzechów Manassesa oraz proroctwa przeciwko Jerozolimie i Judzie czytelnik mógłby oczekiwać realizacji Bożego wyroku w postaci kary wymierzonej bezpośrednio w sprawcę wykroczeń, czyli samego króla. Zakończenie opowiadania w $2 \mathrm{Krl} 21$ nic o tym jednak nie mówi. Historiograf podaje najpierw stereotypową konkluzję rządów monarchy, zgodnie z konwencją Ksiąg Królewskich (w. 17), by następnie poinformować o jego pochówku w ogrodzie pałacowym i ustanowieniu jego syna Amona nowym królem Judy (w. 18). Informacja, że Manasses spoczął ze swoimi przodkami w grobie, zakłada spokojną i niegwałtowną śmierć. Historiograf nie wspomina nic o ewentualnej karze, jaką Bóg mógłby wymierzyć bezpośrednio Manassesowi, choćby w postaci wojny czy przelania jego krwi w odpłacie za dokonane zbrodnie. Można przyjąć zatem, że wina i kara za grzechy Manassessa nie zostały zmazane i obciążyły jego lud, zgodnie z biblijnym konceptem odpowiedzialności zbiorowej za winę króla (por. przypadek króla Dawida w 2Sm 24, 17). ${ }^{8}$ Warto zauważyć, że w warstwie konstrukcyjnej opowiadania oznacza to suspens w fabule, który domaga się dokończenia i rozwiązania.

Tradycja o Manassesie w Księgach Królewskich nie ogranicza się tylko do $2 \mathrm{Krl} 21$. Jego postać jest przywołana jeszcze trzykrotnie. Dwa razy ma to miejsce w kontekście działań jego wnuka, króla Jozjasza, który odnowił przymierze z Bogiem po bezbożnych rządach swego dziadka Manassesa i ojca Amona (2Krl 23, 1-3). Historiograf podaje, że zniósł on wszystkie miejsca kultu bałwochwalczego w Judzie, w tym ołtarze pogańskie, które Manasses sporządził w świątyni jerozolimskiej $(23,12)$. Reformy Jozjasza nie odwróciły jednak losów jego królestwa. Bóg bowiem nie zaniechał „,zaru wielkiego gniewu”, którym ,zapłonął przeciw Judzie za wszystkie zniewagi,

8 Por. R.D. N e 1 s o n, I e II Re, Strumenti. Commentari 51, Torino 2010, s. 273; K.A.D. S m e $1 \mathrm{i}$ k, Converting the Past: Studies in Ancient Israelite and Moabite Historiography, s. 160-163. 
jakimi obraził go Manasses $(23,26)$ ". ${ }^{9}$ Stwierdzenie to oznacza rychłe odrzucenie Judy, Jerozolimy i świątyni jako miejsca przebywania Jego imienia (w. 27) oraz ostateczną realizację wyroku ogłoszonego w $2 \mathrm{Krl} 21,11-15$.

Rozwiązanie fabuły z $2 \mathrm{Krl} 21$ następuje w toku wydarzeń przytoczonych w $2 \mathrm{Krl} 24-25$. Przy okazji najazdu wojsk Nabuchodonozora, króla babilońskiego, w celu rozgromienia buntu króla Jojakima $(24,1-2)$ historiograf wyjaśnia, że stało się to z rozkazu Boga JHWH jako skutek grzechów Manassesa, a szczególnie z powodu niewinnej krwi, w której zatopił Jerozolimę, tak że Bóg nie chciał już tego przebaczyć (ww. 3-4). Przywołanie postaci Manassesa w tym kontekście czyni go bezpośrednim winowajcą i odpowiedzialnym za narodową katastrofę, której skutki poniosą wszyscy mieszkańcy Jerozolimy i Judy. ${ }^{10}$ Te wyjaśnienia historiografa stanowią jedyny komentarz teologiczny do wydarzeń w $2 \mathrm{Krl} 24-25$, co skłania do wniosku, że również następne wydarzenia (tj. zburzenie świątyni, zniszczenie Jerozolimy i uprowadzenie króla Jojakina oraz ludności Judy do Babilonu) należy odczytywać w relacji do nieodkupionej winy Manassesa. W ten sposób wyrocznia Boża i zapowiedź zagłady z 21, 11-15 znajdują wreszcie swoje wypełnienie, a fabuła opowiadania o Manassesie - swoje rozwiązanie i zakończenie.

\section{Rehabilitacja Manassesa w 2 Krn 33, 10-20}

W innym kierunku rozwija się opowiadanie o Manassesie w Księgach Kronik. W relacji Kronikarza bezbożny król i bałwochwalca oraz jego lud (2Krn 33,1-9) otrzymali upomnienie od Boga, którego nie przyjęli (w. 10), dlatego Pan sprowadził przeciw nim wojska

9 O nieodwołalnym losie Judy wypowiada się także prorokini Chulda w $2 \mathrm{Krl} 22$, 16-17, ale bez odniesień do winy Manassesa.

10 Zob. szczegółowe studium w: K. K i n o w s k i, Dlaczego Juda została zniszczona przez Nabuchodonozora? Teologiczna reinterpretacja przelania niewinnej krwi przez króla Manassesa $(2 \mathrm{Krl} 21,16)$ w $2 \mathrm{Krl} 24$, 3-4, Zeszyty Naukowe Stowarzyszenia Biblistów Polskich 14/2017, s. 331-345. 
asyryjskie, by zakuły władcę w kajdany i uprowadziły do Babilonu (w. 11). Działania te są wyraźną karą Bożą za grzechy Manassesa według zasady retrybucji. Kronikarz wyraża w ten sposób ścisły związek przyczynowo-skutkowy między grzechami króla a karzącą interwencją Boga, tak że nie może być ona odroczona czy odłożona w czasie, jak w przypadku opowiadania Ksiąg Królewskich. Należy zauważyć, że Kronikarz podkreśla przy tym indywidualny charakter kary Bożej (wymierzonej bezpośrednio w Manassesa), podczas gdy temat kary w wymiarze zbiorowym (wobec ludu) jest niejako przemilczany. ${ }^{11}$

Boża interwencja w 2Krn 33, 10-11 staje się w sensie narracyjnym tzw. czynnością transformującą w całym opowiadaniu i punktem zwrotnym, gdyż wydarzenia te skłoniły Manassesa do przebłagalnej pokuty przed Bogiem i otworzyły mu drogę powrotu do Jerozolimy (ww. 12-13a). W konstrukcji tego opowiadania punktem kulminacyjnym czy też szczytowym w budowaniu napięcia dramatycznego jest komentarz Kronikarza, że w ten oto sposób Manasses zrozumiał, że tylko sam JHWH jest Bogiem (w. 13b).

Nawrócenie i powrót króla do Jerozolimy oznaczały nie tylko rehabilitację, ale też nowy początek jego rządów. Wyrazem tego stały się reforma religijna oraz dzieła odnowy królestwa, którym Manasses poświęcił się. Kronikarz donosi o jego przedsięwzięciach architektonicznych (nowy podwyższony mur zewnętrzny Jerozolimy, w. 14a) ${ }^{12}$ i militarnych (reorganizacja wojska i wzmocnienie jego obecności we wszystkich miastach warownych Judy, w. 14b). Historiograf szczegółowo opowiada o usunięciu kultu bałwochwalczego

${ }_{11}$ Zob. Ph. A b a d i e, From the Impious Manasseh (2 Kings 21) to the Convert Manasseh (2 Chronicles 33): Theological Rewriting by the Chronicler, s. 98-99.

12 Badacze wskazują na podobieństwo między budową nowego muru w Jerozolimie przez Manassesa (2Krn 33,14a), a odbudową murów miasta przez Nehemiasza (Ne 2, $17-4,23$ ), co miałoby wskazywać na kontekst historyczny tej wzmianki; zob. L.K. H a n dy, Rehabilitating Manasseh: Remembering King Manasseh in the Persian and Hellenistic Periods, w: D.V. E d e $1 \mathrm{~m}$ a n, E. B e $\mathrm{n}$ Zvi (red.), Remembering Biblical Figures in the late Persian and Early Hellenistic Periods: Social Memory and Imagination, Oxford 2013, s. 225-226. 
ze świątyni i całej Jerozolimy (w. 15), a także o odbudowie ołtarza Pańskiego i złożeniu na nim ofiar oraz pouczeniu ludu o wyłącznej służbie Bogu JHWH (w. 16). ${ }^{13} \mathrm{~W}$ ten sposób opowiadanie podkreśla przeciwieństwo między wcześniejszymi bezbożnymi czynami króla (ww. 3-4), a jego reformą religijną jako działaniami naprawczymi (ww. 14-16)..$^{14}$

Końcowe fragmenty opowiadania wspominają jeszcze o modlitwie Manassesa, ${ }^{15}$ którą skierował do Boga w swoim utrapieniu. Kronikarz przywołuje także Kroniki królów Izraela i Kroniki Cho$z a j a$, w których została zapisana zarówno wspomniana modlitwa czy napominające króla proroctwa „widzących”, czy też wszystkie jego grzechy i występki popełnione przed nawróceniem oraz dalsze dzieje monarchy (ww. 18-19). Ostatnie informacje o Manassesie dotyczą jego pochówku w pałacu królewskim oraz faktu, że Amon, jego syn, został kolejnym królem (w. 20). W ten sposób postać Manassesa znika z historiografii Ksiąg Kronik. Symptomatyczne jest to, że jego imię nie pojawia się w kontekście zburzenia Jerozolimy czy niewoli babilońskiej, jak to jest w tradycji Ksiąg Królewskich. W Księgach Kronik winą za katastrofalny koniec królestwa zostaje obarczony

13 Kronikarz zaznacza w w. 17, że lud nadal składał ofiary na wyżynach, ale dodaje, że były to ofiary tylko dla Boga JHWH. Ten komentarz podkreśla indywidualny charakter nawrócenia Manassesa, a także sugeruje, by rozróżnić między „wyżynami” jako miejscami nieprawowiernego kultu w Księgach Królewskich (według teologii deuteronomistycznej dopuszczającej kult jedynie w świątyni jerozolimskiej) a „wyżynami” jako lokalnymi miejscami kultu jahwistcznego w Księgach Kronik; zob. Ph. A b a d i e, From the Impious Manasseh (2 Kings 21) to the Convert Manasseh (2 Chronicles 33): Theological Rewriting by the Chronicler, s. 100 .

14 G.N. Knoppers zauważa, że reforma Manassesa nie odwróciła wszystkich skutków jego wcześniejszych działań i okazała się niewystarczająca, by powstrzymać upadek Judy; zob. G.N. K n o p p e r s, Saint or Sinner?: Manasseh in Chronicles, s. 224-226.

15 Tekst biblijny nie podaje treści tej modlitwy. Wzmianka o niej dała prawdopodobnie początek tekstowi znanemu pod nazwą Modlitwa Manassesa, odnalezionemu w Qumran (4Q381 33, 8-11; 45, 1-7). Znana jest także niezależna grecka wersja Modlitwy Manassesa, która znajduje się w Septuagincie jako dodatek. 
cały naród: najpierw ustami prorokini Chuldy (34, 23-28) a następnie głosem narratora $(36,14-16)$. Gniew Boga na swój lud wzmógł się tak bardzo, że nie było dla niego żadnego ratunku (w. 16).

Wizerunek Manassesa jako nawróconego grzesznika, który w wyniku interwencji Bożej i nieuniknionej kary stał się odnowicielem i budowniczym Judy, jest alternatywnym obrazem, odcinającym się od tradycji o tym królu znanej z 2Krl 21. W opowiadaniu Kronikarza nie ma nic $\mathrm{z}$ tonu Ksiąg Królewskich obciążających Manassesa winą za zburzenie Jerozolimy i upadek Królestwa Judy. Kronikarz milczy też na temat jego zbrodni przelania niewinnej krwi. W efekcie kreśli on pozytywny obraz Manassesa, widząc w nim wezwanie grzeszników do nawrócenia, a poszukiwanie przebaczenia u Boga stawia za wzór godny naśladowania.

\section{Konstrukcja opowiadań o Manassesie}

Lektura obydwu opowiadań o Manassesie prowadzi do oczywistego wniosku, że charakteryzują się one odmienną konstrukcją. Podczas gdy obie narracje bazują początkowo na tym samym obrazie króla jako grzesznika i bałwochwalcy, Księgi Królewskie rozwijają fabułę w kierunku dalszego napiętnowania Manassesa jako mordercy i przyczyny upadku narodu, a Księgi Kronik - w kierunku jego rehabilitacji jako pokutnika i odnowiciela. Dlaczego jednak Kronikarz nie wspomina o przelaniu przez Manassesa niewinnej krwi w Jerozolimie? Dlaczego pomija jego winę w doprowadzeniu Królestwa Judy do upadku, a kładzie taki nacisk na jego rehabilitację? Dlaczego historiograf Ksiąg Królewskich nic nie mówi o najeździe asyryjskim i uwięzieniu Manassesa, ani o jego reformach czy przedsięwzięciach budowlanych i militarnych? Dlaczego obarcza go winą za katastrofę narodową, która miała miejsce ponad 40 lat po jego śmierci?

Każde z powyższych pytań wiąże się z nadrzędnym założeniem, które już w tym miejscu trzeba przyjąć i stwierdzić, że kryterium doboru materiału historycznego dla obydwu hagiografów była 
odpowiednia do zamierzonego przez nich celu strategia narracyjna wynikająca z przesłanek teologicznych. ${ }^{16}$

Strategia narracyjna w opowiadaniu Ksiąg Królewskich

Opowiadanie o Manassesie w Księgach Królewskich można interpretować na trzech płaszczyznach: prawnej, kultycznej oraz w relacji do zasady odpłaty. ${ }^{17}$ Dynamika wydarzeń widzianych w perspektywie prawnej wskazuje na przymierze $\mathrm{z}$ Bogiem i wynikające $\mathrm{z}$ niego Prawo jako podstawowe kryterium teologiczne w ocenie postępowania Manassesa. ${ }^{18}$ Jego bezbożne postępowanie oraz odrzucenie prawowiernego kultu Boga JHWH, a nade wszystko, zbezczeszczenie świątyni jerozolimskiej przez umieszczenie w niej ołtarzy pogańskich i posągu bożka, było nie tylko złamaniem Prawa (zob. Pwt 13, 2-19), ale także zakwestionowaniem przymierza z Bogiem. Wystarczy wspomnieć, że jedną z pierwszych czynności reformatorskich króla Jozjasza, wnuka Manassesa, było odnowienie przymierza (2Krl 23, 1-3), a zatem należy przyjąć, że zostało ono wcześniej złamane. W związku z tym wyrok Boży przeciwko Jerozolimie i Judzie (2Krl 21, 11-15) trzeba interpretować na płaszczyźnie prawnej jako konsekwencję odstępstwa od przymierza, czyli od wyłącznej służby Bogu JHWH. Przywołanie w tym kontekście losów Samarii i rodu Achaba (w. 13a) potwierdza przypuszczenie, że upadek Królestwa Izraela był w oczach historiografa paradygmatem dla losów Judy.

16 I. W. Provan zaznacza, że Księgi Królewskie są tylko jednym z „obrazów” przeszłości Izraela, który można było „namalować”; zob. I.W. P r o v a n, 1 and 2 Kings, Old Testament Guides, Sheffield 1997, s. 53. Ta uwaga dotyczy także historiografii Ksiąg Kronik.

17 Zob. K. K i n ow s k i, Motyw ,gniewu Bożego” w historiografii Ksiąg Królewskich, Verbum Vitae 34/2018, s. 62-64.

$18 \mathrm{Z}$ paradygmatu prawnego wynika też typowa dla teologii deuteronomistycznej sekwencja grzech i jego osąd (ang. crime and punishment) oraz proroctwo i jego wypełnienie się (ang. prophecy and fulfillment); zob. G. vo n R a d, Studies in Deuteronomy, Studies in Biblical Theology 9, London 1956, s. 74-91; t e n ż e, Old Testament Theology, t. I, New York 1962, s. 334-347. 
Teologiczne uzasadnienie upadku Samarii w 2Krl 17, 7-23 (a szczególnie ww. 15-17) wskazuje na wiele grzechów, które później (z punktu widzenia czasu narracji) znajdą się na liście występków Manassesa w $2 \mathrm{Krl}$ 21, 1-9. W efekcie historiograf interpretuje upadek Judy jako konsekwencję tych samych grzechów, które doprowadziły do tragicznego końca Królestwo Izraela. Podobną funkcję pełni porównanie Manassesa do króla Achaba, okrzykniętego największym bałwochwalcą i mordercą niewinnych w historii Izraela (zob. niżej - wnioski). W ten sposób paradygmat prawny zbudowany na fundamencie wierności przymierzu i Prawu jest podstawowym kryterium teologicznym zarządzającym historiografią Ksiąg Królewskich.

Druga płaszczyzna interpretacyjna tej perykopy odnosi się do kultu. Wyszczególnienie tylko jednego i bardzo konkretnego występku Manassesa, mianowicie, zbrodni przelania niewinnej krwi jako bezpośredniej przyczyny najazdu babilońskiego i zniszczenia Judy (2Krl 24, 1-4), nie jest tu bez znaczenia. Jak wspomniano wcześniej w kontekście intertekstualnym, bezprawne przelanie krwi sprowadza na ziemię nieczystość kultyczną (Lb 35, 33a, por. Ps 106,38; Ez 36,18). ${ }^{19} \mathrm{~W}$ przypadku Manassesa tylko przelanie jego krwi mogłoby odkupić zaciągniętą winę, co - jak wiemy - nie zdarzyło się, gdyż król umarł w spokojnej starości (zob. powyżej komentarz do $2 \mathrm{Krl} 21,18)$. Oznacza to, że kraj splamiony winą za przelanie niewinnej krwi nie doczekał się oczyszczenia. Nawiązuje do tego wyrocznia Boża w 2Krl 21, 13b, która za pomocą metafory wytarcia i odwrócenia misy do góry dnem mówi o zagładzie Jerozolimy i Judy dokonującej się w celu usunięcia nieczystości ziemi. W płaszczyźnie kultycznej mamy więc do czynienia z interpretacją wydarzeń według schematu: nieprawne przelanie krwi - splamienie ziemi krwią - oczyszczenie

19 Zob. T. Fr y me r-Ken s k y, Pollution, Purification, and Purgation in Biblical Israel, w: C.L. M e y e r s, M. O' C o n n or (red.), The Word of the Lord Shall Go Forth: Essays in Honor of David Noel Freedman in Celebration of His Sixtieth Birthday, American School of Oriental Research. Special Volume Series 1, Winona Lake 1983, s. 399-414; Y. F e d e r, Blood Expiation in Hittite and Biblical Ritual: Origins, Context, and Meaning, Writings From the Ancient World. Supplement Series 2, Atlanta 2011, s. 176. 
przez zniszczenie. ${ }^{20} \mathrm{~W}$ ten oto sposób przywołanie motywu przelania niewinnej krwi przez Manassesa w kontekście zniszczenia Judy przez wojska Nabuchodonozora (2Krl 24, 1-4) znalazło swoje teologiczne uzasadnienie. Wydaje się, że zagłada Jerozolimy i Judy były w oczach historiografa Ksiąg Królewskich koniecznym działaniem oczyszczającym ziemię i odkupieniem win zaciągniętych przez Manassesa.

Opowiadanie o Manassesie w Księgach Królewskich można ponadto odczytać w kluczu znanym ze starożytnych historiografii, a mianowicie w relacji do zasady odpłaty (sprawiedliwości retrybucyjnej). Według niej za wyrządzone zło należy odpłacić tą samą miarą (zob. Wj 21, 23-25; Kpł 24, 19-20). Tak więc krwawe zbrodnie Manassesa wołają o pomstę równie okrutną, a przywołanie w tym kontekście postaci króla Achaba w 2Krl 21, 13a może mieć podwójny sens: nie tylko odnosić się do jego bałwochwalstwa według wspominanego powyżej paradygmatu prawnego, ale także przywoływać zasadę odpłaty. W oskarżeniu wniesionym przez proroka Eliasza przeciwko Achabowi w 1Krl 21, 19 czytamy bowiem, że psy będą lizały krew króla w tym samym miejscu, gdzie wylizały wcześniej krew niewinnego Nabota, zamordowanego za jego przyzwoleniem (21, 6-7). Wniosek jest oczywisty: śmierć Achaba była dla historiografa odpłatą za śmierć Nabota (zob. 22, 37-38). Według tej samej zasady można interpretować zagładę ludności Judy podczas najazdu babilońskiego jako adekwatną karę za krwawe przestępstwa Manassesa. Podobny schemat odnajdziemy także w wypowiedzi proroka Ozeasza odnośnie do losów Królestwa Północnego. Zapowiada on w Oz 14, 1 krwawe działania Asyryjczyków wobec ludności Izraela (rozpruwanie brzuchów ciężarnych kobiet), takie same jak cierpienia zadane podbitym ludom przez Menachema, króla Izraela $(2 \mathrm{Krl} 15,16){ }^{21}$

20 Zob. T. Fr y m e r-Ke n s k y, Pollution, Purification, and Purgation in Biblical Israel, s. 399, 409-410. Warto wspomnieć, że podobną logikę zawierają niektóre metafory proroków (zob. Iz 4,4; Ez 24, 6. 11-13).

21 Zob. P. D u b o v s k ý, Menahem's Reign before the Assyrian Invasion (2Kings 15:14-16), w: D.S. V a n d e r h o of t, A. W i n it z e r (red.), Literature as Politics, Politics as Literature: Essays on the Ancient Near East in Honor of Peter Machinist, Winona Lake 2013, s. 29-45. 
Powyższe trzy płaszczyzny interpretacji opowiadania o Manassesie ujawniają strategię narracyjną historiografa Ksiąg Królewskich. Jej celem było ukazanie Manassesa jako anty-króla, ${ }^{22}$ największego bałwochwalcę i mordercę swoich poddanych, przewyższającego bezbożnością najgorszych nawet monarchów, gotowego skazać Królestwo Judy na taki sam los, jaki spotkał Królestwo Izraela. Nie może zatem w 2Krl 21, 1-18 być miejsca na jakikolwiek pozytywny akcent w ocenie rządów Manassesa, czy tym bardziej na wzmiankę o jego nawróceniu i rehabilitacji, jak w Księgach Kronik. Nietrudno zauważyć teraz, że obraz króla Manassesa w historiografii Ksiąg Królewskich jest nakreślony tendencyjnie i został wyraźnie nacechowany teologicznie po to, by uczynić z niego głównego odpowiedzialnego za narodową tragedię jako „kozła ofiarnego" 23 i - być może - umniejszyć $\mathrm{w}$ ten sposób winę (po)wygnaniowej wspólnoty za doprowadzenie kraju do upadku. ${ }^{24}$

22 Koncept,,anty-władcy” zaproponował R. G i r a r d, Violence and the Sacred, Baltimore 1977, s. 77-78, 96-99, 107-109, 302-306.

23 Wiele studiów ukazuje Manassesa jako „kozła ofiarnego” teologicznej interpretacji dziejów; zob. m.in. S. L a s i n e, Manasseh as Villain and Scapegoat, w: J.Ch. Ex u m, D.J.A. C 1 i n e s (red.), The New Literary Criticism and the Hebrew Bible, JSOT.SS 143, Sheffield 1993, s. 163-183; K. S c h m i d, Manasse und der Untergang Judas: ,Golaorientierte” Theologie in den Königsbüchern? Biblica 78/1997, s. 87-99; B. H a l p e r n, Why Manasseh Is Blamed for the Babylonian Exile: The Evolution of a Biblical Tradition, Vetus Testamentum 48/1998, s. 473-514; F. S t a v r a k o p o u 1 o u, The Blackballing of Manasseh, w: L.L. G r a b b e (red.), Good Kings and Bad Kings, LHB.OTS 393, London 2005, s. 248-263; J. S c h i p p e r, Hezekiah, Manasseh, and Dynastic or Transgenerational Punishment, w: M. L e $\mathrm{u} \mathrm{c}$ h t e r, K.-P. A d a m (red.), Soundings in Kings: Perspectives and Methods in Contemporary Scholarship, Minneapolis 2010, s. 81-105, 187-194; E.A. K n a u f, The Glorious Days of Manasseh, w: t e n ż e, Data and Debates: Essays in the History and Culture of Israel and Its Neighbors in Antiquity - Daten un Debatten: Aufsätze zur Kulturgeschichte des antiken Israel und seiner Nachbarn, Alter Orient und Altes Testament 407, Münster 2013, s. 251-275.

24 Zob. S. L a s i n e, Manasseh as Villain and Scapegoat, s. 166-167, 174; K. S c h m i d, Manasse und der Untergang Judas: „Golaorientierte“ Theologie in den Königsbüchern? s. 93, 96-99. 
Strategia narracyjna w opowiadaniu Ksiąg Kronik

Opowiadanie Kronikarza wpisuje się w inną strategią narracyjną, chociaż jej podstawą jest również paradygmat prawny i zasada bezpośredniej retrybucji. ${ }^{25}$ Punkt wyjścia jest ten sam: Manasses jest bezbożnikiem i bałwochwalcą także w Księgach Kronik, który swoim postępowaniem złamał przymierze z Bogiem JHWH i w konsekwencji zasłużył na surową karę. W odróżnieniu jednak od Ksiąg Królewskich narracja Ksiąg Kronik poszerzona jest o wątek Bożej interwencji skierowanej bezpośrednio do króla. Od tego momentu narracja Kronikarza rozwija się w zupełnie innym kierunku niż w Księgach Królewskich. Uprowadzenie Manassesa do Babilonii jest karą Bożą, którą król ponosi osobiście. To doświadczenie staje się dla niego punktem zwrotnym i pozwala mu zrozumieć, że jedynym Bogiem jest JHWH (2Krn 33, 13b). Ukorzenie się przed Nim, prośba o przebaczenie oraz podjęte nawrócenie pozwoliły Manassesowi doświadczyć nie tylko Bożego miłosierdzia, ale także otworzyły mu drogę powrotu do ojczyzny oraz dały możliwość osobistej rehabilitacji. W ten sposób narracja Ksiąg Kronik dodaje do paradygmatu prawnego (przymierze - złamanie przymierza - kara) kolejne elementy, tj. nawrócenie i odnowienie (rehabilitacja). Jest to dobrze znany schemat narracyjny Kronikarza (grzech - kara - nawrócenie odnowienie; zob. paradygmat w $2 \mathrm{Krn} 7,14)$, który pełni w jego dziele ważną funkcję perswazyjną względem społeczności wygnańców, adresatów Ksiąg Kronik. ${ }^{26}$ Manasses, nawrócony grzesznik, który po przywróceniu do łask zrehabilitował się jako odnowiciel i budowniczy Judy, mógł być dla wygnańców doskonałym wzorem do

25 G.N. K n o p p e r s, Saint or Sinner?: Manasseh in Chronicles, s. 215-217.

26 Zob. W.M. S c h n i e d e w ind, The Source Citations of Manasseh: King Manasseh in History and Homily, Vetus Testamentum 41/1991, s. 451-455, 460-461; por. S. J a p h e t, I and II Chronicles: A Commentary, Old Testament Library, Louisville 1993, s. 1001. 
naśladowania, gdyż dawał nadzieję na powrót do utraconej ojczyzny oraz odnowę jej państwowości. ${ }^{27}$

Dlaczego jednak Kronikarz nie wzmiankuje o Manassesowym przelewie krwi? Dlaczego nie obciąża go winą za sprowadzenie klęski narodowej, jak czyni to historiograf Ksiąg Królewskich? Wydaje się, że odpowiedzi na te pytania kryją się w przedstawionej powyżej strategii narracyjnej Kronikarza. Obraz Manassesa dokonującego krwawej rzezi w Jerozolimie nie współbrzmi z pozytywnym przesłaniem historiografa Ksiąg Kronik. O ile bowiem król mógł zrehabilitować się przed Bogiem za swoje odstępstwa i bałwochwalstwo, przeprowadzając reformę religijną w kraju i usuwając elementy wprowadzonego przez siebie kultu bałwochwalczego, o tyle wydaje się niemożliwe, lub bardzo trudne, by zrehabilitować się za odebranie życia niewinnym ludziom. ${ }^{28}$ Ponadto wzmianka o przelaniu niewinnej krwi przez Manassesa oznaczałaby zaciągnięcie przez niego kultycznej nieczystości (zob. uwagi do $2 \mathrm{Krl} 21,16),{ }^{29}$ a to uczyniłoby go niezdolnym do odnowienia kultu świątynnego. ${ }^{30}$ Jest zatem prawdopodobne, że Kronikarz intencjonalnie przemilczał kwestię morderstw Manassesa ze względów teologicznych i perswazyjnych, potrzebował bowiem przekazać swoim odbiorcom pozytywny obraz króla jako przykładu do naśladowania.

27 Ph. Abadie ukazuje, że postać Manassesa jest w Księgach Kronik typiczną figurą konwertyty i dobitnym przykładem skuteczności nawrócenia; $\mathrm{Ph}$. A b a d i e, From the Impious Manasseh (2 Kings 21) to the Convert Manasseh (2 Chronicles 33): Theological Rewriting by the Chronicler, s. 98-99, 102-104.

28 Pokutujący heretyk ma szansę zadośćuczynić za swoją grzeszną przeszłość, ale tyran-morderca, nawet jeżeli się nawróci, nie przywróci życia swoim ofiarom; zob. L.K. H a n d y, Rehabilitating Manasseh: Remembering King Manasseh in the Persian and Hellenistic Periods, s. 224.

29 D.F. Murray wykazuje na podstawie analizy 1Krn 22, 8; 28, 3, że syntagmat ,przelać krew” (hebr. šsāpak dām) implikuje w Księgach Kronik zaciągnięcie kultycznej nieczystości; D.F. M u r r a y, Under YHWH's Veto: David As Shedder of Blood in Chronicles, Biblica 82/2001, s. 457-476.

30 Zob. L.K. H a n d y, Rehabilitating Manasseh: Remembering King Manasseh in the Persian and Hellenistic Periods, s. 224. 
W podobny sposób można wytłumaczyć, dlaczego Kronikarz nie odniósł się do osobistej odpowiedzialności Manassesa za upadek Judy i wygnanie babilońskie. Kronikarz mówi wyraźnie o winie całego ludu, który do tego stopnia szydził i lekceważył napominających go Bożych wysłanników, że nie było już dla niego ratunku (2Krn 36, 16). Umieszczenie zbiorowej odpowiedzialności Judejczyków za sprowadzenie nieszczęścia na swój kraj w miejscu indywidualnej winy Manassesa jest również konsekwencją przyjętej przez Kronikarza strategii narracyjnej. Miała ona oddziaływać na postawę społeczności powygnaniowej, pośród której nikt nie powinien czuć się zwolniony z odpowiedzialności za naród: ani jako spadkobierca jego bolesnej przeszłości, ani jako budowniczy jego przyszłości. Pod tym względem przesłanie teologiczne Ksiąg Kronik jest bardziej uniwersalne od opowiadania Ksiąg Królewskich i pozostaje aktualne także dla dzisiejszych czytelników Pisma Świętego: nawrócenie i uznanie JHWH za jedynego Boga otwiera największemu nawet grzesznikowi drogę do pojednania i odnowy.

\section{Manasses Biblii versus Manasses historii}

Obecność dwóch różnych tradycji biblijnych o Manassesie skłania do zadawania pytań o „historycznego” Manassesa. Który obraz tej postaci - z Ksiąg Królewskich czy z Ksiąg Kronik - jest bliższy prawdzie historycznej? Jakie są możliwości i granice historycznej rekonstrukcji postaci Manassesa? ${ }^{31}$

Należy wpierw zauważyć, że obydwa nurty tradycji o Manassesie znajdują swoje potwierdzenie w literaturze pozabiblijnej. $\mathrm{Z}$ jednej

31 Wielu biblistów odrzuca historyczny charakter szczegółów podanych w opowiadaniu Ksiąg Kronik, a nieobecnych w Księgach Królewskich. B.E. Kelly przedstawia ciekawą dyskusję z tą tezą i ukazuje, że nie powinno się bezkrytycznie odrzucać historyczności kronikarskiego obrazu Manassesa; zob. B.E. K e 11 y, Manasseh in the Books of Kings and Chronicles (2 Kings 21:1-18; 2 Chron 33:1-20), w: V.Ph. L o n g, D.W. B a k e r, G.J. W e $\mathrm{n}$ h a $\mathrm{m}$ (red.), Windows into Old Testament History: Evidence, Argument, and the Crisis of "Biblical Israel", Grand Rapids 2002, s. 131-146. 
strony Talmud ${ }^{32}$ i apokryficzne Męczeństwo Izajasza utrwalają negatywny obraz Manassesa jako bałwochwalcy i mordercy proroków (król miał zamordować proroka Izajasza, przecinając go piłą na pół ${ }^{33}$ ). Z drugiej zaś strony apokryficzna Modlitwa Manassesa podbudowuje jego pozytywny wizerunek jako nawróconego grzesznika. ${ }^{34}$ Trzeba wspomnieć ponadto, że grecka wersja Ksiąg Królewskich i Ksiąg Kronik nie przypisuje zbrodni przelania niewinnej krwi Manassessowi, lecz królowi Jojakimowi (zob. tekst starogrecki 4 Królestw 24, 4 w wersji tzw. Manuskryptów Lucjańskich oraz $2 \operatorname{Krn}^{\text {LXX }} 36,5$ ). To z niego Septuaginta czyni głównego winowajcę najazdu babilońskiego, umniejszając tym samym odpowiedzialność Manassesa za narodową tragedię. ${ }^{35} \mathrm{Z}$ tych obserwacji wynika, że obydwa nurty tradycji o Manassesie istniały w świadomości narodu wybranego niezależnie, jako dwie alternatywne (re)interpretacje tej samej postaci historycznej. ${ }^{36}$

Czy w tej sytuacji jest możliwa rekonstrukcja historycznej postaci Manassesa? Nasze analizy wykazały, że obydwa obrazy króla są nacechowane teologicznie. Zarówno narracji z Ksiąg Królewskich, jak i z Ksiąg Kronik, przyświeca przede wszystkim cel teologiczny i pragmatyczny, nadrzędny wobec zdarzeń historycznych, które bywają rekonstruowane dopiero po dziesiątkach lat czy nawet

32 Traktat Tosefty Kippurim (1,12g-h) obarcza Manassesa winą za to, Bóg opuścił miejsce swojego „zamieszkania” w Jerozolimie; por. traktaty Talmudu Babilońskiego: Shabbath 33a oraz Yoma 9b, a także misznaicki traktat 'Abot 5,9b.

33 Zob. Męczeństwo Izajasza 11, 41. Morderstwo Izajasza przypisują Manassesowi także manuskrypt f6 Targumu Jonatana do 2Krl 24, 4, Targum do Iz 66,1, Talmud Babiloński (Yevamos 49b i San 103b) i Jerozolimski (Sanhedrin 10:2:vii.g-i), Midrasz Pesikta Rabbati 4, 3 oraz Józef Flawiusz w Dawnych dziejach Izraela (X 38).

34 Wzmianka o modlitwie Manassesa znajduje się także w apokryficznej 2Bar $(64,8)$ oraz w rabinackiej rozprawie Mekilta Bahodesh $(10)$.

35 Zob. F. S t a v r a k o p o u 1 o u, King Manasseh and Child Sacrifice: Biblical Distortions of Historical Realities, s. 39-40.

36 Zob. L.K. H a n d y, Rehabilitating Manasseh: Remembering King Manasseh in the Persian and Hellenistic Periods, s. 234-235. 
wiekach. ${ }^{37}$ Dlatego też dotarcie do historycznej postaci Manassesa jest utrudnione, a być może nawet niemożliwe, gdyż w obu przypadkach widzimy go przez pryzmat założeń teologicznych i strategii narracyjnych, przyjętych przez danego historiografa.$^{38} \mathrm{Każda} \mathrm{próba}$ historycznej rekonstrukcji biblijnych wydarzeń i postaci musi liczyć się z tymi założeniami.

Jakie zatem przyjąć kryteria oceny źródeł, gdy próbujemy ustalić fakty historyczno-biograficzne z życia króla Manassesa? Odpowiadając na to pytanie, należy wziąć pod uwagę przede wszystkim trzy kryteria. Pierwsze z nich zostało sformułowane przez greckiego filozofa Anaksagorasa z Kladzomen (V w. przed Chr.), który mówił o tradycjach przekazywanych z pokolenia na pokolenie, że nic się w nich nie traci, niczego się w nich nie wymyśla, wszystko natomiast podlega transformacji. Mając to na uwadze, nie powinno się odrzucać a priori żadnej informacji o Manassesie, którą podaje Pismo Święte, ale należy pamiętać, że mogła ona $\mathrm{z}$ biegiem czasu i ze względów teologicznych ulec znacznej transformacji.

Trzeba do powyższego dodać jeszcze bardzo ważny element świadomości starożytnego świata, a mianowicie ścisły związek między historią jako zbiorem wydarzeń z przeszłości a tzw. pamięcią zbiorową, społeczną (social memory), odpowiadającą za ich selekcję, porządkowanie i przekazywanie w społeczeństwach niepiśmiennych czy

37 J.-L. Ska ukazuje, że celem tekstów biblijnych było kształtowanie świadomej wiary Izraela bardziej niż podawanie informacji na temat jego przeszłości; zob. J.-L. S k a, Les énigmes du passé: Histoire d'Israël et récit biblique, Le livre et le rouleau 14, Brussels 2001. Zob. także dyskusję F. Stavrakopoulou na temat różnicy między nacechowanymi teologicznie opowiadaniami biblijnymi (ang. story) a historią jako taką (ang. history) w: F. S t a v r a k o p o u 1 o u, King Manasseh and Child Sacrifice: Biblical Distortions of Historical Realities, s. 1-13.

38 Zob. W.M. S c h n i e d e w ind, The Source Citations of Manasseh: King Manasseh in History and Homily, s. 451-455, 460-461. F. Stavrakopoulou uważa, że historyczna postać Manassesa została zniekształcona w opowiadaniach biblijnych; F. S t a v r a k o p o u 1 o u, King Manasseh and Child Sacrifice: Biblical Distortions of Historical Realities, s. 100; por. M. C o g a n, H. T a d m o r, II Kings: A New Translation with Introduction and Commentary, Anchor Bible 11, New Haven-London 2008², s. 291. 
wysoce zanalfabetyzowanych. Historiografie starożytne są owocem pamięci zbiorowej, chociaż jednocześnie to one ją kształtują i transformują. Dlatego też istotne jest pytanie nie tylko o historyczność wydarzeń biblijnych, ale także o przesłanki teologiczne, dla których przetrwały one w pamięci społecznej w danej formie. Historiografie biblijne zajmują się bowiem interpretacją wydarzeń i dokonują ich rewizji bardziej niż weryfikacji czy falsyfikacji. ${ }^{39}$

Trzecim kryterium oceniającym charakter źródła informacji jest zasada historycznego uprawdopodobnienia, która mówi, że w przypadku braku dowodów na potwierdzenie lub zaprzeczenie danego wydarzenia należy rozważyć, w jakim stopniu jest ono jedynie możliwe z punktu widzenia historycznego, a na ile jest prawdopodobne. W przypadku króla Manassesa kryterium to ma szczególne zastosowanie, gdyż nie dysponujemy jednoznacznymi dowodami potwierdzającymi szczegóły z jego biblijnego życiorysu. Należy przy tym pamiętać, że takie rekonstrukcje są zawsze hipotetyczne.

W związku z powyższym jest prawdopodobne, że „historyczny” Manasses nie był ani tak jednoznacznie złym królem, jak przedstawiają go Księgi Królewskie, ani tak godnym wzorem do naśladowania, jak w Księgach Kronik. ${ }^{40}$ Zapewne rozszerzył kult na „wyżynach” w Judzie według praktyk powszechnie stosowanych przez ludy Kanaanu. ${ }^{41}$ Prawdopodobnie przelał czyjąś krew

39 Zob. zwięzłą prezentację teorii pamięci społecznej i jej zastosowanie do studiów biblijnych w: R. W i 11 i a m s, Social Memory, Biblical Theology Bulletin 41(2011) nr 4, s. 189-200. Zob także E. B e n Z v i, On Social Memory and Identity Formation in Late Persian Yehud: A Historian's Viewpoint with a Focus on Prophetic Literature, Chronicles, and the Dtr. Historical Collection, w: L. J o n k e r (red.), Texts, Contexts and Readings in Postexilic Literature Explorations into Historiography and Identity Negotiation in Hebrew Bible and Related Texts, Forschungen zum Alten Testament. 2. Reie 53, Tübingen 2011, s. 95-148.

40 Zob. dyskusję w B.E. K e 11 y, Manasseh in the Books of Kings and Chronicles (2 Kings 21:1-18; 2 Chron 33:1-20), s. 138-146.

${ }^{41}$ Jak zauważają historycy religii, praktyki kultyczne stosowane przez Manassesa nie były ani „obce”, ani pozbawione elementów jahwizmu. Były raczej częścią normatywnego i rodzimego politeizmu w Judzie, w który należy włączyć kult JHWH jako jego ważny element; zob. P. M e r l o, La religione dell'antico Israele, 
w Jerozolimie, ale niekoniecznie niewinną i na pewno nie w takiej mierze, żeby wypełnić nią całe miasto. ${ }^{42}$ Nie można wykluczyć, że Manasses - jako wierny wasal króla Asyrii - był na jego dworze (w inskrypcjach asyryjskich jego imię kilkakrotnie pojawia się wśród zachodnich lenników Asyrii ${ }^{43}$ ), chociaż trudno wyrokować na temat charakteru tej wizyty (uprowadzenie?) ze względu na brak źródeł pozabiblijnych, mówiących o inwazji asyryjskiej za czasów Manassesa (ok. 697-642 przed Chr.). ${ }^{44}$ Jest natomiast wysoce prawdopodobne, że przez długie 55 lat swoich rządów Manasses wzniósł wspomniany mur w Jerozolimie oraz nowe budowle w Judzie, poprawiając w ten sposób obronność kraju, zwłaszcza że odkrycia archeologiczne zdają się to potwierdzać. ${ }^{45}$

Quality Paperbacks 291, Roma 2009, s. 45-47. Odnowienie tzw. wyżyn za czasów Manassesa mogło być wynikiem ponownego zasiedlenia wiejskich terenów w Judzie po inwazji króla asyryjskiego Sennacheryba; zob. F. S t a v r a k o p o u l o u, King Manasseh and Child Sacrifice: Biblical Distortions of Historical Realities, s. 110.

${ }^{42}$ W świetle polityki imperium neoasyryjskiego Manasses, jak każdy wasal Asyrii, mógł cieszyć się daleko posuniętą wolnością w polityce wewnętrznej i pozbywać się ,niewygodnych” poddanych tak długo, jak wasalne status quo było niezagrożone; zob. K. K i n o w s k i, Dlaczego Juda została zniszczona przez Nabuchodonozora? Teologiczna reinterpretacja przelania niewinnej krwi przez króla Manassesa $(2 \mathrm{Krl} 21,16)$ w $2 \mathrm{Krl}$ 24, 3-4, s. 344.

${ }^{43}$ Zob. tekst num. 1, v 55 oraz tekst num. 5, vi 7' w: E. L e i c h ty, The Royal Inscriptions of Esarhaddon, King of Assyria (680-669 BC), The Royal Inscriptions of the Neo-Assyrian Period 4, Winona Lake 2011, s. 9, 44; zob. także pryzmę C, ii 39 w: R. B o r g e r, Beiträge zum Inschriftenwerk Assurbanipals: Die Prismenklassen $A, B, C=K, D, E, F, G, H, J$ und $T$ sowie andere Inschriften, Wiesbaden 1966, s. 18, 212.

${ }^{44}$ Znaleziska archeologiczne wskazują na brak śladów działań wojennych w Judzie między końcem VIII w. przed Chr. (inwazja Sennacheryba w 701 r. przed Chr.) a początkiem VI w. przed Chr. (najazdy Nabuchodonozora między 597 a 586 r. przed Chr.), co oznacza, że rządy Manassesa przebiegały pokojowo, bez większych konfliktów zbrojnych. Zob. ogólną prezentację danych archeologicznych z tego okresu w: L.L. G r a b b e, The Kingdom of Judah from Sennacherib's Invasion to the Fall of Jerusalem: If We Had Only the Bible, w: t e n ż e (red.), Good Kings and Bad Kings, LHB.OTS 393, London 2005, s. 81-90, 101-104.

${ }_{45}$ K. Kenyon odkryła mur w Jerozolimie niedaleko źródła Gihon na wschodnim zboczu miasta Dawidowego, datowany na VIII-VII w. przed Chr, czyli na czasy 
Historia Manassesa w 2Krn 33, 1-20 przedstawia alternatywną do opowiadania z Ksiąg Królewskich (2Krl 21, 1-18) wersję dziejów tego władcy i przekreśla jednoznacznie negatywny jego obraz. W tym sensie Księgi Kronik całościowo reinterpretują tę postać biblijną, wzbogacając jej życiorys o nieznane dotąd szczegóły, przechowywane w pamięci zbiorowej wygnańców. Przykład bezbożnego króla, który się nawrócił i odnowił religijnie oraz architektonicznie Judę, miał na celu wzywać powygnaniowych adresatów Ksiąg Kronik do wejścia na drogę pokuty i pojednania z Bogiem, aby wzorem Manassesa mogli doświadczyć Bożego miłosierdzia i z nadzieją spojrzeć na możliwość narodowej odnowy. Przesłanie to pozostaje aktualne także dla dzisiejszych czytelników historii Manassesa.

\section{ks. Krzysztof KINOWSKI}

Słowa kluczowe: Księgi Kronik; Księgi Królewskie; król Manasses; teologia historii

Keywords: Books of Chronicles; Books of Kings; king Manasseh; theology of history

Ezechiasza lub Manassesa. Ponadto, archeolodzy datują powstanie kilku judzkich budowli (np. Ramat Rahel, Horvat Uza) na VII w. przed Chr. Świadczą one o rozwoju struktur organizacyjno-urzędowych i ogólnie dobrym stanie państwa. Badacze nie są jednak jednomyślni w interpretacji tych danych archeologicznych. Niektórzy z nich przypisują nowe projekty budowlane Manassesowi (I poł. VII w. przed Chr.), a niektórzy - jego wnukowi Jozjaszowi (II poł. VII w. przed Chr.) lub jego ojcu Ezechiaszowi (gdy chodzi o mur w Jerozolimie; II poł. VIII w. przed Chr.). Brak materiału porównawczego uniemożliwia, niestety, dokładniejszą datację, zob. L. Tatu m, King Manasseh and the Royal Fortress at Horvat 'Uza, Biblical Archaeologist 54/1991, s. 136-145; I. F i n k e 1 s t e i n, The Archaeology of the Days of Manasseh, w: M.D. C o o g a n, J.Ch. E x u m, L.E. S t a g e r, J.A. G r e e n e (red.), Scripture and Other Artifacts: Essays on the Bible and Archaeology in Honor of Philip J. King, Louisville 1994, s. 177. 


\title{
Reinterpretation of History in the Books of Chronicles. The Case of King Manasseh
}

\author{
Summary
}

The narrative about King Manasseh in the Second Book of Chronicles (33:1-20) is an interesting example of the reinterpretation of historical material found in the Books of Kings. In the first part (2 Chr 33: 1-9) the Chronicler picks up the details of the plot about Manasseh from $2 \mathrm{Kgs}$ 21:1-9 and forms thus its parallel narrative. In the second part (2 Chr 33:10-20) he presents, however, his own material about Manasseh which is absent in the narrative of the Books of Kings (cf. 2 Kgs 21:10-18). In effect, the Books of Chronicles shed different light on the reign of our king. Whereas the Books of Kings present Manasseh as the most impious Judean king, idolater and murderer of the innocent Judahites, causing the fall of his kingdom and its inhabitants who became destined for an exile into Babylon, the Books of Chronicles build up a positive image of Manasseh. Here, he is a sinner who, punished by God, humbled himself before Him and converted, and after his rehabilitation carried out religious reforms and devoted himself to construction works, renewing thus the splendour of the Kingdom of Judah. This alternative tradition about Manasseh harmonises perfectly with the theological message of the Books of Chronicles, since its narrative about Manasseh depicts a well-recognized pattern of the Chronicler, namely sin - punishment - conversion - restoration, which was particularly important to the postexilic community. In Manasseh's destiny it could reread its own history as punishment for idolatry and unfaithfulness to God, who is willing to forgive its trespasses and restore its lost splendour if it returns to Him. This interrelated link between God's forgiveness, restoration and conversion is a universal truth, tangible also in today's addresses of the Holy Scripture. 


\section{Bibliografia}

$\mathrm{A} \mathrm{b}$ a d i e Ph., From the Impious Manasseh (2 Kings 21) to the Convert Manasseh (2 Chronicles 33): Theological Rewriting by the Chronicler, w: Graham M.P., McKenzi e S.L., Knoppers G.N. (red.), The Chronicler as Theologian: Essays in Honor of Ralph W. Klein, Journal for the Study of the Old Testament. Supplement Series 371, London-New York 2003, s. 89-104.

B e n Zv i E., On Social Memory and Identity Formation in Late Persian Yehud: A Historian's Viewpoint with a Focus on Prophetic Literature, Chronicles, and the Dtr. Historical Collection, w: J o n k e r L. (red.), Texts, Contexts and Readings in Postexilic Literature Explorations into Historiography and Identity Negotiation in Hebrew Bible and Related Texts, Forschungen zum Alten Testament. 2. Reie 53, Tübingen 2011, s. 95-148.

B o r g e r R., Beiträge zum Inschriftenwerk Assurbanipals, Wiesbaden 1966.

C o g a n M., T a d m o r H., II Kings: A New Translation with Introduction and Commentary, Anchor Bible 11, New Haven-London $2008^{2}$.

D u bovs ký P., Menahem's Reign before the Assyrian Invasion (2 Kings 15:14-16), w: Va nd e r h o of t D.S., W in it z e r A. (red.), Literature as Politics, Politics as Literature: Essays on the Ancient Near East in Honor of Peter Machinist, Winona Lake 2013, s. 29-45.

F e d e r, Y., Blood Expiation in Hittite and Biblical Ritual: Origins, Context, and Meaning, Writings From the Ancient World. Supplement Series 2, Atlanta 2011.

F in k e l s t e in I., The Archaeology of the Days of Manasseh, w: C o o g a $\mathrm{n}$ M.D., E x u m J.Ch., S t a g e r L.E., G r e e n e J.A. (red.), Scripture and Other Artifacts: Essays on the Bible and Archaeology in Honor of Philip J. King, Louisville 1994, s. 169-187.

Frymer-Kensky T., Pollution, Purification, and Purgation in Biblical Israel, w: M e y e r s C.L., O ' C o n n o r M. (red.), The Word of the Lord Shall Go Forth: Essays in Honor of David Noel Freedman in Celebration of His Sixtieth Birthday, American School of Oriental Research. Special Volume Series 1, Winona Lake 1983, s. 399-414.

G i r a r d R., Violence and the Sacred, Baltimore 1977.

$\mathrm{G} \mathrm{r}$ a b b e L.L., The Kingdom of Judah from Sennacherib's Invasion to the Fall of Jerusalem: If We Had Only the Bible, w: t e n ż e (red.), Good Kings and Bad Kings, Library of Hebrew Bible. Old Testament Studies 393, London 2005, s. 78-122.

$\mathrm{H}$ a $\mathrm{lp}$ e r n B., Why Manasseh Is Blamed for the Babylonian Exile: The Evolution of a Biblical Tradition, Vetus Testamentum 48/1998, s. 473-514. 
$\mathrm{H}$ a n d y, L.K., Rehabilitating Manasseh: Remembering King Manasseh in the Persian and Hellenistic Periods, w: E d e $1 \mathrm{~m}$ a n D.V., B e n Zv i E.(red.), Remembering Biblical Figures in the late Persian and Early Hellenistic Periods: Social Memory and Imagination, Oxford 2013, s. 221-235.

J a p h e t S., I and II Chronicles: A Commentary, Old Testament Library, Louisville 1993.

Ke 11 y B.E., Manasseh in the Books of Kings and Chronicles (2 Kings 21:1-18; 2 Chron 33:1-20), w: L o n g V.Ph., B a ke r D.W., We n h a m G.J. (red.), Windows into Old Testament History: Evidence, Argument, and the Crisis of "Biblical Israel", Grand Rapids 2002, s. 131-146.

$\mathrm{K}$ e $\mathrm{u}$ l e $\mathrm{n}$ v a n P.S.F., Manasseh through the Eyes of the Deuteronomists: The Manasseh Account (2 Kings 21:1-18) and the Final Chapters of the Deuteronomistic History, Oudtestamentische studiën 38, Leiden 1996.

K in ow s k i K., Dlaczego Juda została zniszczona przez Nabuchodonozora? Teologiczna reinterpretacja przelania niewinnej krwi przez króla Manassesa (2Krl 21, 16) w 2Krl 24, 3-4, Zeszyty Naukowe Stowarzyszenia Biblistów Polskich 14/2017, s. 331-345.

K i n ow s k i K., Motyw „gniewu Bożego” w historiografii Ksiąg Królewskich, Verbum Vitae 34/2018, s. 37-66.

$\mathrm{K} \mathrm{n}$ a u f E.A., The Glorious Days of Manasseh, w: t e $\mathrm{n} \dot{\mathrm{z}} \mathrm{e}$, Data and Debates: Essays in the History and Culture of Israel and Its Neighbors in Antiquity Daten un Debatten: Aufsätze zur Kulturgeschichte des antiken Israel und seiner Nachbarn, Alter Orient und Altes Testament 407, Münster 2013, s. 251-275.

K n o p p e r s G.N., Saint or Sinner?: Manasseh in Chronicles, w: C o r$1 \mathrm{e}$ y J., v on G rol H.W.M. (red.), Rewriting Biblical History: Essays on Chronicles and Ben Sira in Honor of Pancratius C. Beentjes, Berlin-New York 2011, s. 211-229.

$\mathrm{L}$ a $\mathrm{s}$ in e S., Manasseh as Villain and Scapegoat, w: E x u m J.Ch., C 1 in e s D.J.A. (red.), The New Literary Criticism and the Hebrew Bible, Journal for the Study of the Old Testament. Supplement Series 143, Sheffield 1993, s. $163-183$.

L e i c h t y E., The Royal Inscriptions of Esarhaddon, King of Assyria (680$-669 B C$ ), The Royal Inscriptions of the Neo-Assyrian Period 4, Winona Lake 2011.

M e r lo P., La religione dell'antico Israele, Quality Paperbacks 291, Roma 2009.

M u r r a y D.F., Under YHWH's Veto: David As Shedder of Blood in Chronicles, Biblica 82/2001, s. 457-476. 
$\mathrm{Ne} 1 \mathrm{~s}$ o n R.D., I e II Re, Strumenti. Commentari 51, Torino 2010.

P r o v a n I.W., 1 and 2 Kings, Old Testament Guides, Sheffield 1997.

R a d v o n G., Old Testament Theology, t. I, New York 1962 [wyd. pol.: Teologia Starego Testamentu, tłum. B. W i d ł a, Warszawa 1986].

R a d v o n G., Studies in Deuteronomy, Studies in Biblical Theology 9, London 1956.

$\mathrm{S}$ c h i p p e r J., Hezekiah, Manasseh, and Dynastic or Transgenerational Punishment, w: L e u c ht e r M., A d a m K.-P. (red.), Soundings in Kings: Perspectives and Methods in Contemporary Scholarship, Minneapolis 2010, s. 81-105, 187-194.

S c h m i d K., Manasse und der Untergang Judas: „Golaorientierte“ Theologie in den Königsbüchern? Biblica 78/1997, s. 87-99.

$\mathrm{S} \mathrm{c} \mathrm{h} \mathrm{n}$ i e d e w in d W.M., The Source Citations of Manasseh: King Manasseh in History and Homily, Vetus Testamentum 41/1991, s. 450-461.

$\mathrm{S}$ k a J.-L., Les énigmes du passé: Histoire d'Israël et récit biblique, Le livre et le rouleau 14, Brussels 2001.

$\mathrm{S}$ m e $1 \mathrm{i}$ k K.A.D., Converting the Past: Studies in Ancient Israelite and Moabite Historiography, Oudtestamentlische Studiën 28, Leiden-New York-Köln 1992.

S t a v r a k o p o u lou F., The Blackballing of Manasseh, w: G r a b b e L.L. (red.), Good Kings and Bad Kings, Library of Hebrew Bible. Old Testament Studies 393, London 2005, s. 248-263.

$\mathrm{S}$ t a v r a k o p o u 1 o u F., King Manasseh and Child Sacrifice: Biblical Distortions of Historical Realities, Beihefte zur Zeitschrift für die alttestamentliche Wissenschaft 338, Berlin 2004.

T a t u m L., King Manasseh and the Royal Fortress at Horvat 'Uza, Biblical Archaeologist 54/1991, s. 136-145.

W i 11 i a m s R., Social Memory, Biblical Theology Bulletin 41(2011) nr 4, s. $189-200$. 